\title{
Economic Analysis of Tractor Powered Manure Pulverizer cum Applicator over Traditional Manure Application Practices
}

\author{
S. Sai Mohan ${ }^{1}$, P. Babu², P.R. Jayan ${ }^{1}$
}

10.18805/ag.D-5341

\begin{abstract}
Background: A well-managed manure is a valuable resource in providing nutrients for crop production. Farmers usually follow manual manure application practices which involves lot of drudgery and physical stress to pulverize as well as to apply in field. Also traditional practices results in a reduced field capacity along with higher cost of application. So there is a need to create a medium between the farmers and manure application practices by introducing manure pulverizers and applicators. Hence a study was undertaken to analyze the economic impact of a tractor powered manure pulverizer cum applicator over traditional practices. Methods: A manure pulverizer cum applicator helps in managing the manure by simultaneous pulverization and application in the field as basal application. On the other hand traditional practices involve manual dumping, clearing of lumps and spreading them in the field which require more than 3 labours to cover an acre in a day. Cost incurred with both manual and mechanical practices were calculated in terms of rupees per hour and rupees per hectare of operation.

Result: The actual field capacity and efficiency of manure pulverizer cum applicator was observed to be 0.311 ha $\mathrm{h}^{-1}$ and $86.5 \%$ at a forward speed of $2.0 \mathrm{~km} / \mathrm{h}^{-1}$. The cost of manure pulverizer cum applicator alone was Rs. 64,000. Cost of operation of manure pulverizer cum applicator as an attachment to tractor was found to be $1943.5 \mathrm{Rs} \mathrm{ha}^{-1}$. Cost of manual manure application followed by manure pulverization was noted as $4662.2 \mathrm{Rs} \mathrm{ha}^{-1}$. Saving in cost of operation was more than Rs. 2700 with tractor operated manure pulverizer cum applicator over manual application practices. The benefit-cost ratio of the developed machine was 1.4:1.
\end{abstract}

Key words: Application rate, Benefit:cost ratio, Break even point, Drudgery, Manure.

\section{INTRODUCTION}

Manures (FYM, vermicompost, oil cakes etc.,) are important resources which provide nutrients that could reduce bagged fertilizer costs and improve the crop growth and performance. As agriculture is facing the problems of soil degradation, loss of fertility and soil health, the use of livestock waste, manure and organic materials is the only way out. A larger portion of nitrogen is made available when the manure decomposes. A well-managed manure is a valuable resource in providing nutrients for crop production. Use of farm yard manure and other organic manure is the way out to overcome the problems of soil degradation, loss of fertility and soil health (Elizabeth et al., 2012). Also, the application of recommended doses of manure at the proper time would stabilize the soil fertility status and hence improves soil productivity.

Utilization of livestock waste for agriculture is an important activity carried out by farmers. Livestock waste viz., cow dung, goat droppings etc., are collected, dried and then spread in the field. Manure produced from the livestock provides a lot of humus, increases soil fertility and helps in achieving improved crop productivity. Studies suggest that pulverizing dried manure into fine powder before applying it in the field helpsin easy absorption (Julienne et al., 2010). Manure gets decomposed as soon as it put on the soil by the action of microorganisms present in the soil (KAU POP, 2016). To speed up the decomposition process, it is necessary to break up the manure clods and make more surface area exposed for the attack of microorganisms (James and Roger, 2000).

Studies revealed that fine powder is easily absorbed by the soil and easy to handle due to decreased volume and
${ }^{1}$ Department of Farm Machinery and Power Engineering, Kelappaji College of Agricultural Engineering and Technology, Kerala Agricultural University, Tavanur-679 573, Kerala, India.

${ }^{2}$ Department of Process and Food Engineering, Kelappaji College of Agricultural Engineering and Technology, Kerala Agricultural University, Tavanur-679 573, Kerala, India.

Corresponding Author: S. Sai Mohan, Department of Farm Machinery and Power Engineering, Kelappaji College of Agricultural Engineering and Technology, Kerala Agricultural University, Tavanur -679 573, Kerala, India. Email: samalasaimohan@gmail.com

How to cite this article: Mohan, S.S., Babu, P. and Jayan P.R. (2022). Economic Analysis of Tractor Powered Manure Pulverizer Cum Applicator over Traditional Manure Application Practices. Agricultural Science Digest. DOI: 10.18805/ag.D-5341.

Submitted: 08-04-2021 Accepted: 17-01-2022 Online: 21-02-2022

more nutrient concentration (Jotautiene and Bivainis, 2017). Problems like drift and drudgery caused due to manual manure spreading resulted in health problems. In manual spreading, energy is consumed during clods clearing and spreading and still leaves the field with non-uniform distribution of manure. Improper and inaccurate broadcasting causes abnormal and non-homogeneous soil fertility which is against to the purpose of sustainable agriculture.

Due to the availability of large farming area, heavy equipment's like solid and liquid manure applicators are commonly used in developed countries. The manure spreading has become mechanized in other countries but in India the indigenous methods are still followed, i.e., a loaded 
trolley or bullock cart is moved in the field and stopped at regular interval where a man other than the driver unloads a small amount of manure in the form of a heap. These heaps are later spread around manually with spades, which is laborious, tedious, uneconomical and time consuming process. The existing practice of leaving manure in small heaps scattered in the fields prior to the field application for a very long period lead to loss of nutrients (Mohan and Jayan, 2021).

Studies revealed that the net returns per acre was less in case organic farming (OF) compared to conventional farming because of the labour intensive nature of OF while weeding (Kumara and Dwivedi, 2010). Due to these manual practices lot of man-hours are consumed which further increases the cost of operation. In view of these, there is always a need for using innovative manure applicator machines in the farm. Hence, this research work was carried out to compare the costs incurred in traditional manure application practices with tractor powered manure pulverizer cum applicator.

\section{Physical properties of manure}

Physical properties of manure directly affect the clod size, pulverization capacity, design of blower and manure dissipation (Sahay and Singh, 2001). Less dense nature of the manure results in decreased pulverization capacity and application rate and on the other hand as the moisture content increases it retards the spreading and pulverization process (Reddy and Reddy, 2017). The important physical properties of pulverized manure are moisture content, bulk density, angle of repose, terminal velocity and coefficient of friction.

Physical properties of the manure effected the manure discharge rate through the blower. Bulk density of manure was found to be $0.195 \pm 0.01 \mathrm{~g} \mathrm{~cm}^{-3}$ for cow dung, $0.492 \pm 0.01$ $\mathrm{g} \mathrm{cm}^{-3}$ for goat droppings and $0.520 \pm 0.01 \mathrm{~g} \mathrm{~cm}^{-3}$ for neem cake. Denser manure gets deposited at the corners and on the other hand less dense manure creates drift due to atmospheric wind. Increase in the moisture content of manure due to improper storage and climatic changes result in unsatisfactory pulverization and application. Hence sun dried manure was preferred for clump free pulverization which helps in easy handling and application (Landry et al., 2004). Tapped density of manure was found to be $0.308 \pm 0.01 \mathrm{~g} \mathrm{~cm}^{-3}$ for cow dung, $0.668 \pm 0.01 \mathrm{gcm}^{-3}$ for goat droppings and

$0.748 \pm 0.01 \mathrm{~g} \mathrm{~cm}^{-3}$ for neem cake. Angle of repose was found to be $43 \pm 0.1$ for cow dung, $37 \pm 0.1$ for goat droppings and $38 \pm 0.1$ for neem cake. Optimum angle of repose of the pulverized manure helped in easy flow ability, suction and conveying of manure during working condition.

\section{MATERIALS AND METHODS}

The application rate of various manure was observed for different crops according to the agronomic conditions of Kerala state. To overcome the drudgery involved in manual manure application practices as well as to promote modern manure application practices, a study was undertaken to develop a tractor powered manure pulverizer cum applicator. The components of the machine were developed to suit the various dosages of manure without much variation in the distribution efficiency. Costs incurred with mechanical practices are compared in detail with traditional manure application practices.

Major row crops like tomato, okra, brinjal and chilli are selected to study the spacing and dosage requirements as shown in Table 1 for noting down the time consumed to apply specified manure quantity in the field with both traditional practices and manure pulverizer cum applicator. The manhours spent in covering the field and achieving the dosage requirements are useful in cost of operation calculations.

\section{Traditional manure application practices}

Manual manure application involves dumping clumps of manure in the field, crushing them and finally spreading them in rows as shown in Fig 1. To cover over a hectare of land with labour, it takes a lot of man hours and field capacity will also be less. It was noted that almost $8 \mathrm{~h}$ were consumed for applying 1 ha of land with 3 labours.

Table 1: Recommended dosage of manure for various row crops (POP KAU, 2016).

\begin{tabular}{lcc}
\hline Crop & Spacing $(\mathrm{cm} \times \mathrm{cm})$ & Dosage, $\mathrm{t} \mathrm{ha}^{-1}$ \\
\hline Tomato & $60 \times 60$ & $20-25$ \\
Okra & $60 \times 45$ & 12 \\
Brinjal & $60 \times 60$ & $20-25$ \\
Chilli & $45 \times 45$ & $20-25$ \\
\hline
\end{tabular}

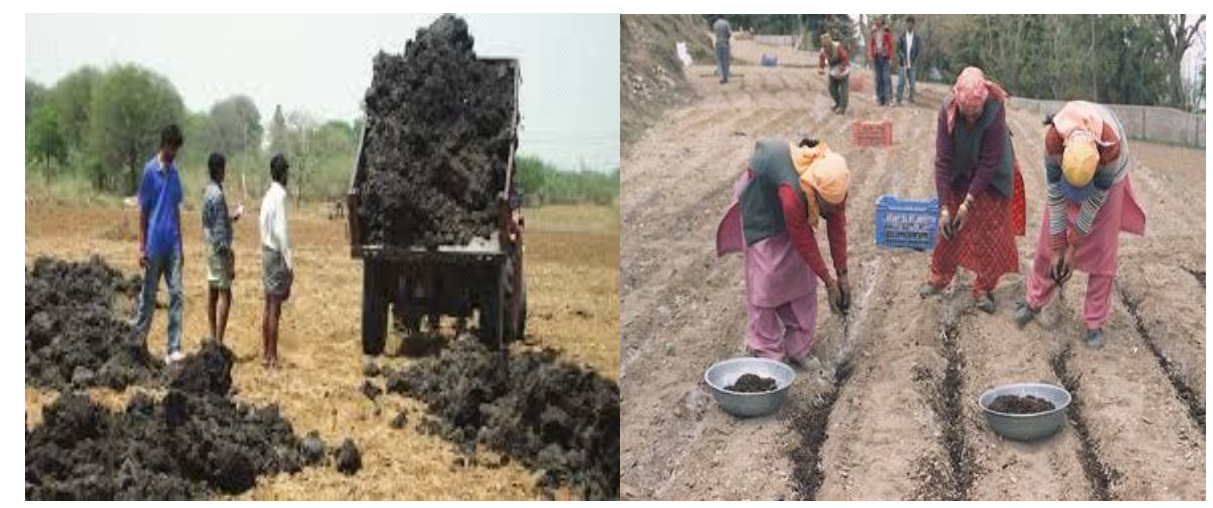

Fig 1: Dumping and spreading of manure by labours. 


\section{Tractor powered manure pulverizer cum applicator}

In the agriculture field level, a tractor is the most commonly available power source. Hence a manure pulverizer cum applicator unit was made as a tractor attachment with PTO as prime mower. The developed parts viz., KAU manure pulverizer, feed chute, blower, frameandhitch, gearbox and extension shaft were assembled as shown in Fig 2. Existing KAU manure pulverizer (Jayan et al., 2017) was utilized for pulverizing except that its power source has been replaced with gearbox. The supporting frame was made large enough to accommodate all the supporting parts. KAU manure pulverizer was fixed on the supporting frame with nut and bolt making it a removable part. Pulverizer powdered the dried manure which was then collected in the chute below the pulverizer unit. Deposited manure gets sucked through the inlet into the blower unit and discharged through the outlets. Provisions were made to adjust the valve opening, pulverizer blade rpm and blower rpm. Flexible pipes provided at the outlets help in achieving different swath widths in the field. Failure in the model and factor of safety were analysed using theoretical considerations following ASTM standards (Jegan and Jerry, 2017).

\section{Cost economics}

Fixed cost and variable cost of the tractor drawn manure pulverizer cum applicator was calculated as per the procedure described by IS: $9164-1979$. From the field capacity of the machine the cost of operation per hectare and cost of operation per hour was calculated.

Also traditional practices of manure application was studied and capacity of the manual labours (man-hours ha-1) was determined. Based on this, the costs incurred in both traditional and mechanical manure application was compared. Breakeven point, payback period and benefit cost ratio were also determined.

\section{Break-even point}

The break-even point is defined as the point at which neither profit is made nor loss incurred. Breakeven analysis, also called a point of no profit-loss is performed to assess the duration of work at a given price that is necessary to meet

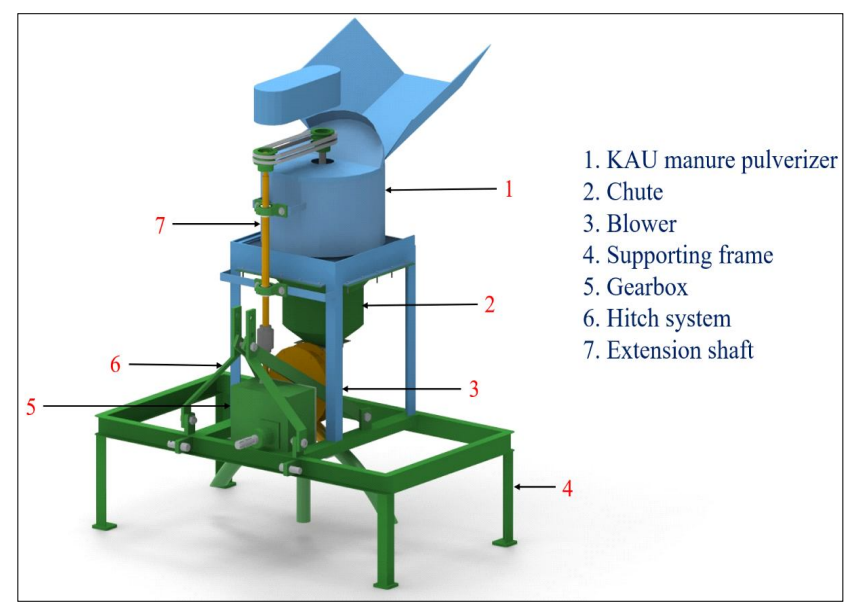

Fig 2: Manure pulverizer cum applicator. out all the costs or expenditures. The breakeven point is the intersection of the lines at which the line of total cost and the line of custom hiring cost intersect each other. If the breakeven point value is less than the annual utility time of machinery then the farmer benefitted by owning a machine. If the breakeven point value is found more than the annual utility time of machinery then owning machinery can lead to a loss for the farmer, where custom hiring is the better option for him.

The break-even point is equal to the annual fixed cost divided by difference between the custom rate per hour and the operating cost per hour. The break-even calculation can be done either with graphical method or by formulation. It was calculated as

$$
\text { Break-even point, } \mathrm{h} \mathrm{yr}^{-1}=\frac{\mathrm{AFC}}{\mathrm{CF}-\mathrm{C}}
$$

(Singh, 2017)

Where,

AFC = Annual fixed cost for the machine, Rs. $\mathrm{yr}^{-1}$

CF $=$ Custom fee, Rs. $h^{-1}$

$\mathrm{C}=$ Operating fee, Rs. $\mathrm{h}^{-1}$

$\mathrm{CF}=($ cost of operation $\mathrm{h}+25 \%$ overhead charges $)+(25 \%$ profit over new cost)

\section{Payback period}

It is the number of year it would take for an investment to return its original cost through the annual cash revenue it generates, if the net cash revenues are constant each year. The payback period was calculated as

Where,

$$
\mathrm{PBP}=\frac{\mathrm{IC}}{\mathrm{ANP}}
$$

(Hunt, 2001)

PEP = Payback period, $y r$

IC = Initial cost of the machine, Rs

ANP $=$ Average net annual profit, Rs $\mathrm{yr}^{-1}$

$\mathrm{ANP}=(\mathrm{CF}-\mathrm{C}) \mathrm{AU}$

$A U=$ Annual use, $h \mathrm{yr}^{-1}$

\section{Benefit cost ratio}

It is defined as the ratio of benefit cost per hectare to the cost of machine application. Benefit cost ratio should be more than one.

Benefit cost per hectare $=$ Cost of manual application - Cost of machine application

Therefore,
Benefit cost ratio, Rs. ha-1 $=\frac{\text { Benefit cost }}{\text { Cost of machine application }}$

(Hunt, 2001)

\section{Annual utility}

It is the average usage of farm machinery or any machine annually. It depends upon how many working days are available for a particular operation with the machine in a year. Annual utility of tractor and the machine was considered as 1000 and 200 hours respectively.

\section{Field testing}

Field testing of prototype manure pulverizer cum applicator was conducted in the farm, KCAET, Tavanur as shown in 
Fig 3. It was attached to $65 \mathrm{hp}$ tractor through three-point linkage and P.T.O was attached to gearbox with a universal joint. Prototype was evaluated at a forward speeds of 2.0 $\mathrm{km} \mathrm{h}^{-1}$ at gear $\mathrm{L}_{1}$ (high), $2.5 \mathrm{~km} \mathrm{~h}^{-1}$ at gear $\mathrm{L}_{2}$ (low) and 3.0 $\mathrm{km} \mathrm{h}^{-1}$ at gear $\mathrm{L}_{2}$ (high).

Laboratory testing was done prior to field evaluation in order to calibrate as well as to note the discharge rate which is further formulated to achieve application rate of manure in the field. Calibration of discharge valves was necessary to achieve uniform spread of manure throughout the field. Field capacity readings of the machine as well as manual application were considered in the cost economics calculations.

\section{RESULTS AND DISCUSSION}

The study was undertaken to analyze the impact of traditional manure application practices over modern techniques. A tractor powered manure pulverizer cum applicator was used to compare the savings in cost and labour with traditional methods. Fixed costs and variable costs are calculated and detailed as shown in Table 2.

\section{Field capacity}

Machine was evaluated at a forward speeds of $2.0 \mathrm{~km} \mathrm{~h}^{-1}$ at gear $L_{1}$ (high), $2.5 \mathrm{~km} \mathrm{~h}^{-1}$ at gear $\mathrm{L}_{2}$ (low) and $3.0 \mathrm{~km} \mathrm{~h}^{-1}$ at gear $L_{2}$ (high). As the forward speed of the machine is increased, the area covered by the machine increases i.e.,

Table 2: Cost economics calculations (Mehta et al., 2019).

\begin{tabular}{|c|c|c|c|}
\hline Sr. no. & Variables & Formula & Cost, Rs $\mathrm{h}^{-1}$ \\
\hline \multicolumn{4}{|l|}{ 1. Tractor } \\
\hline \multicolumn{4}{|l|}{ Fixed cost } \\
\hline 1 & Depreciation & $\frac{}{L \times H}$ & 90 \\
\hline 2 & Interest & $\frac{C+S}{2} \times i$ & 55 \\
\hline 3 & Insurance and taxes & $1.5 \%$ of initial cost & 15 \\
\hline 4 & Housing & $0.5 \%$ of initial cost & 5 \\
\hline \multicolumn{4}{|c|}{ Variable cost } \\
\hline 5 & Fuel cost & Average diesel consumption $=3.5 \mathrm{I} \mathrm{h}^{-1}$ & 192.5 \\
\hline 6 & Lubrication & $10 \%$ of fuel cost & 19.25 \\
\hline 7 & Repair and maintenance & $5 \%$ of initial cost & 50 \\
\hline 8 & Operator wages & Rs. $700 /$ day of 8 hours & 87.5 \\
\hline \multicolumn{4}{|c|}{ Total operating cost of tractor $=$ fixed cost + variable cost $=514.25 \mathrm{Rs} \mathrm{h}^{-1}$} \\
\hline \multicolumn{4}{|c|}{ Fixed cost } \\
\hline 1 & Depreciation & $\mathrm{L} \times \mathrm{H}$ & 28.8 \\
\hline 2 & Interest & $\frac{C+S}{2} \times i$ & 17.6 \\
\hline 3 & Insurance and taxes & $1.5 \%$ of initial cost & 4.80 \\
\hline 4 & Housing & $0.5 \%$ of initial cost & 1.60 \\
\hline \multicolumn{4}{|c|}{ Variable cost } \\
\hline 5 & Repair and maintenance & $5 \%$ of initial cost & 16 \\
\hline \multicolumn{4}{|c|}{ Total operating cost of manure applicator $=$ fixed cost + variable cost $=68.8 \mathrm{Rs} \mathrm{h}^{-1}$} \\
\hline \multicolumn{4}{|c|}{ Field capacity of the machine $=0.311{\text { ha } \mathrm{h}^{-1}}^{-1}$} \\
\hline \multicolumn{4}{|c|}{ Total operating cost of tractor and manure pulverizer cum applicator $=1,943.5 \mathrm{Rs} \mathrm{ha}^{-1}$} \\
\hline \multicolumn{4}{|c|}{ (cost includes pulverizing done with pulverizer + manual application) } \\
\hline \multicolumn{4}{|c|}{ 1. Fixed cost (since pulverization is done with pulverizer), $\mathrm{Rs}^{-1}=63.525$} \\
\hline & Labour cost per person, Rs $\mathrm{h}^{-1}$ & - & 150 \\
\hline & Total labour cost, Rs $\mathrm{h}^{-1}$ & 3 labours & 450 \\
\hline \multicolumn{4}{|c|}{ 2. Variable cost (repairs, electricity cost, labour cost), $\mathrm{Rs} \mathrm{h}^{-1}=19.25+50+450=519.25$} \\
\hline \multicolumn{4}{|c|}{ 3. Total cost of manual manure application, $\mathrm{Rs} \mathrm{h}^{-1}=63.525+519.25=582.775$} \\
\hline \multicolumn{4}{|c|}{ Assuming $8 \mathrm{~h}$ are needed for applying 1 ha of land manually for 3 labours } \\
\hline Total cost of & plication, Rs ha-1 $=582.775 \times 8$ & & \\
\hline
\end{tabular}


Economic Analysis of Tractor Powered Manure Pulverizer Cum Applicator over Traditional Manure Application Practices

its field capacity increases. But at the same time taken to turn and number of fillings increases, as a result its efficiency decreases. Hence increasing the travelling speed resulted in a decreased field efficiency.

The actual field capacity and efficiency of manure pulverizer cum applicator was found out to be 0.311 ha $\mathrm{h}^{-1}$ and $86.5 \%$ at a forward speed of $2.0 \mathrm{~km} \mathrm{~h}^{-1}, 0.356 \mathrm{ha} \mathrm{h}^{-1}$ and $79.2 \%$ at a forward speed of $2.5 \mathrm{~km} \mathrm{~h}^{-1}$ and 0.395 ha $\mathrm{h}^{-1}$ and $73.1 \%$ at a forward speed of $3.0 \mathrm{~km} \mathrm{~h}^{-1}$. Maximum field capacity was noted at a traveling speed of $3.0 \mathrm{~km} \mathrm{~h}^{-1}$ (Mohan and Jayan, 2021). Optimum field capacity reading of machine was taken as $0.311 \mathrm{ha} \mathrm{h}^{-1}$ with $86.5 \%$ efficiency in cost economics calculation.

\section{Cost economics}

The cost economics of tractor powered manure pulverizer cum applicator was calculated as described below. The cost of manure pulverizer cum applicator alone was Rs. 64,000.

Initial assumptions for tractor operated manure pulverizer cum applicator

Initial cost of tractor (C), Rs

Salvage value (S), Rs

Useful life (IS 9164:1979), (L), years : : 10

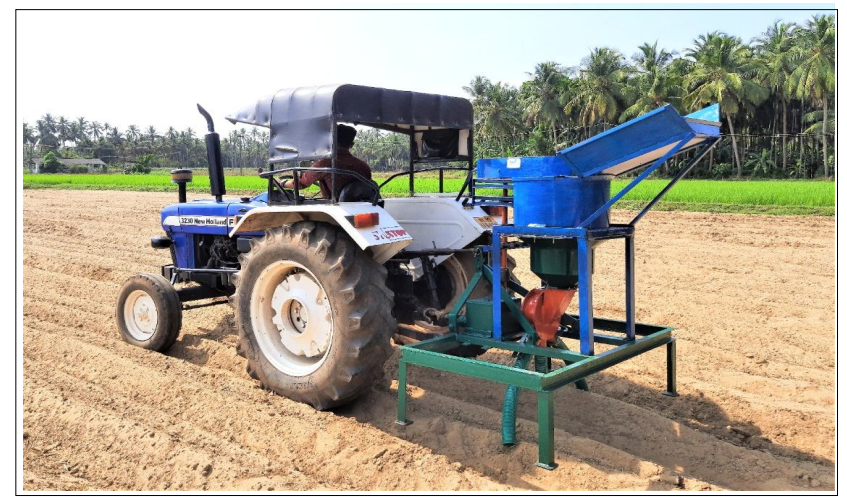

Fig 3: Field evaluation of the developed unit.
Annual usage (IS 9164:1979) of tractor,

$(\mathrm{H})$, hours

1000

Interest rate (i), \%

10

Initial cost of manure pulverizer cum

applicator (C), Rs

64,000

10

Annual usage (IS 9164:1979), (H), hours : 200

Cost of operation of manure pulverizer cum applicator as an attachment to tractor was found as $583.05 \mathrm{Rs} \mathrm{h}^{-1}$ and 1943.5 Rs ha-1 as shown in Fig. 4. Cost of manual manure application followed by manure pulverization was $582.7 \mathrm{Rs}$ $\mathrm{h}^{-1}$ and 4662.2 Rs ha-1.

\section{Determination of breakeven point}

Graphical method was chosen to determine the breakeven point of affording and practicing manure application with developed unit. The point at which the graph between $y=$ $m x+c$ and $y=m x$ coincides is taken as breakeven point. The value of $x$-coordinate indicate the number of hours the machine should be operated in a year to achieve the breakeven. From Fig 5 it is clear that breakeven could be achieved by operating the machine $185 \mathrm{~h} \mathrm{yr}^{-1}$.

Total fixed cost per year, Rs

Total variable cost, $\mathrm{Rs} \mathrm{h}^{-1}$

Custom hiring cost, $\mathrm{Rs} \mathrm{h}^{-1}$

Total area covered per year, ha

Breakeven point, $\mathrm{h} \mathrm{yr}^{-1}$

$\begin{array}{lc}= & 175,560 \\ = & 365.25 \\ = & 1,268.7 \\ = & 60 \\ = & 185\end{array}$

\section{Determination of payback period}

To return the investment through annual cash revenues, the machine should be operated for custom hiring. Custom hiring charges are defined as $25 \%$ over cost of machine operation. Payback period for the machine was calculated as 2.37 yrs.

\section{Determination of benefit cost ratio}

Benefit cost ratio is an indicator that summarize the overall value for money of the machine. Higher the benefit cost ratio greater the profit for the investment and it should always

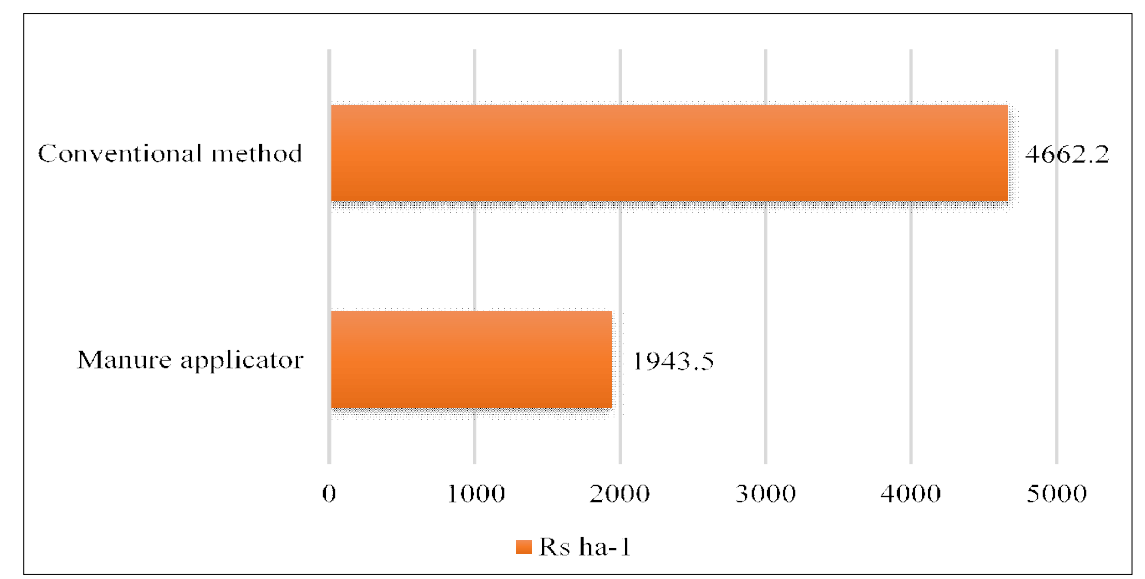

Fig 4: Cost economics of convention practices vs manure applicator. 


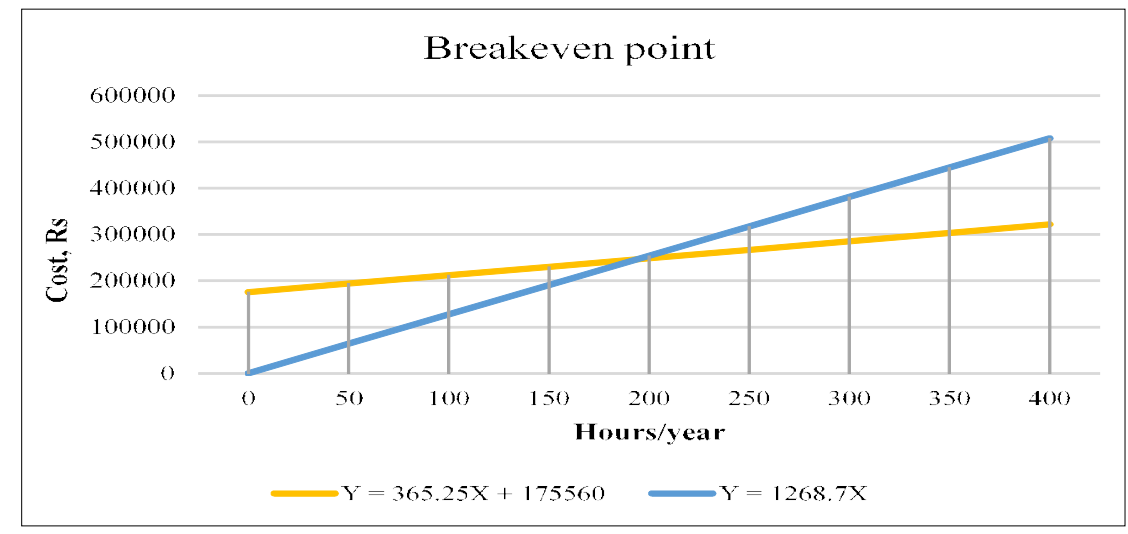

Fig 5: Breakeven point at 185 hrs.

be more than 1 . The benefit-cost ratio of the developed machine was calculated as 1.4:1.

\section{CONCLUSION}

As the population of our country is increasing day by day, there is a need to supply food to each and every individual which can be achieved by increasing the productivity of the crop by supplying enough nutrients to soil with organic manures. Though the chemical fertilizers increase the productivity, it deteriorates the soil qualities and causes imbalance in chemical equilibrium. So application of organic manures is the only way out. Farmers usually follow manual manure application practices which involves lot of drudgery and physical stress to pulverize as well as to apply in the field. So there is a need to create a medium between the farmers and manure application practices by introducing manure pulverizers and applicators. A manure pulverizer cum applicator helps in managing the waste by simultaneous pulverization and application in the field as basal application. The actual field capacity and efficiency of manure pulverizer cum applicator was found out to be $0.311 \mathrm{ha} \mathrm{h}^{-1}$ and $86.5 \%$ at a forward speed of $2.0 \mathrm{~km} \mathrm{~h}^{-1}, 0.356 \mathrm{ha} \mathrm{h}^{-1}$ and $79.2 \%$ at a forward speed of $2.5 \mathrm{~km} \mathrm{~h}^{-1}$ and $0.395 \mathrm{ha} \mathrm{h}^{-1}$ and $73.1 \%$ at a forward speed of $3.0 \mathrm{~km} \mathrm{~h}^{-1}$. The cost of manure pulverizer cum applicator alone was Rs. 64,000. Cost of operation of manure pulverizer cum applicator was found to be 1943.5 Rs ha ${ }^{-1}$. Cost of manual manure application followed by manure pulverization was $4662.2 \mathrm{Rs} \mathrm{ha}^{-1}$. The benefit-cost ratio of the developed machine was 1.4:1. Saving in cost of operation was more than Rs. 2700 with tractor operated manure pulverizer cum applicator over manual application practices.

Conflict of interest: None.

\section{REFERENCES}

Elizabeth, G., Stuart, G. and Marilyn, T. (2012). Manure effects on soil organisms and soil quality. Emerging issues in animal agriculture; 26, November, 2012, Michigan State University Extension. 1-6.
Hunt, D. 2001. Farm power and machinery management. Waveland Press, Inc. pp 77-80.

James, K.P. and Roger, A.B. (2000). Powder flowability. Pharmaceutical Technology. 60-84.

Jayan, P.R., Amal, D.J., Arya, K.T. and Harsha, S. (2017). Machine for pulverization of organic manures. Krishiyankanam. 23(5): 13-14.

Jegan, P. and Jerry Vasanth, P. (2017). Performance analysis of vermicompost spreader with a cultivator. International Journal of Advanced Engineering and Research Development. 4(4): 770-777.

Jotautiene, E. and Bivainis, V. (2017). Investigations on geometrical particle parameters and aerodynamic features of granular manure fertilizers. Engineering for Rural Development. $1452-1457$.

Julienne, A., Lague, C., Schoenau, J. and Feddas, J. (2010). Effect of manure type, application rate and application method on odours from manure spreading. Canadian Biosystems Engineering. 52: 619-629.

KAU (Kerala Agricultural University) (2016). Package of Practices Recommendations: Crops (15 $\mathrm{th}$ d). Kerala Agricultural University Thrissur. pp. 360.

Kumara, C.D. and Dwivedi, A.K. (2010). Economics of organic farming vis-à-vis modern farming in India. Bilingual Journal of Humanities and Social Sciences. 1(2).

Landry, H., Lague, C. and Roberge, M. (2004). Physical and rheological properties of manure products. Applied Engineering in Agriculture. 20(3): 277-288.

Mehta, M.L., Verma, S.R., Misra, S.K. and Sharma, V.K. (2019). Testing and evaluation of agricultural machinery. Daya Publishing House. pp 341-344.

Mohan, S.S. and Jayan, P.R. (2021). Livestock waste utilization through manure pulverizer cum applicator. International Journal of Livestock Research. 11(4): 19-27.

Mohan, S.S. and Jayan, P.R. (2021). Manure pulverizers and applicators: A review. Agricultural Reviews. DOI: https:// dx.doi.org/10.18805/ag.R-2304.

Reddy, T.Y. and Reddy, G.H.S. (2017). Principles of Agronomy (5 $5^{\text {th }}$ Ed.). Kalyani Publishers, New Delhi. pp. 203.

Sahay, K.M. and Singh, K.K. (2001). Unit operations of agricultural processing ( $2^{\text {nd }} E d$.). Vikas Publishing House Pvt Ltd, India. pp. 109.

Singh, T.P. (2017). Farm Machinery. PHI Learning Private Limited. pp: $358-360$. 